\title{
Pengaruh Berbagai Faktor terhadap Brand Switching Handphone pada Mahasiswa Fakultas dan Ekonomi Islam IAIN Palu
}

\author{
Farida Farida $^{1 *}$,Nurwanita Nurwanita ${ }^{2}$, Ferdiawan Ferdiawan $^{3}$ \\ ${ }^{1}$ Jurusan Ekonomi Syariah, Fakultas Ekonomi dan Bisnis Islam, IAIN Palu \\ ${ }^{2}$ Jurusan Ekonomi Syariah, Fakultas Ekonomi dan Bisnis Islam, IAIN Palu, \\ ${ }^{3}$ Jurusan Ekonomi Syariah, Fakultas Ekonomi dan Bisnis Islam, IAIN Palu
}

ABSTRAK

Penelitian ini bertujuan untuk mengetahui apakah berbagai faktor (variety seeking dan fitur produk) berpengaruh terhadap brand switching handphone pada mahasiswa Fakultas Ekonomi dan Bisnis Islam EBI IAIN Palu. Penelitian ini menggunakan metode penelitian kuantitatif. Populasi dalam penelitian ini adalah Mahasiswa IAIN PALU yang berjumlah 885 orang, maka sampel penelitian adalah Mahsiswa FEBI jurusan ekonomi semester 4 dan 6 , yang berjumlah 353 orang. Karena jumlah mahasiswa jurusan ekonomi semester 4 dan 5 jumlahnya 353 maka data kusioner yang disebar sebesar 80 responden untuk mewakili dari jumlah keseluruhan mahasiswa jurusan ekonomi semester 3 dan 6 . Teknik pengambilan sampel yang digunakan adalah stratified sampling dan proportional sampling. Berdasarkan pengolahan data yang dilakukan menggunakan SPSS Statistics21.0 menunjukkan bahwa secara parsial variabel variety seekingberpengaruh positif $(+)$ dan signifikan terhadap brand switching handphone sedangkan variabel fitur produkberpengaruh positif(+) dansignifikan dengan dan secara simultan variabel variety seeking dan fitur produk berpengaruh terhadap brand switching handphone. Serta kedua variabel tersebut secara simultan berpengaruh terhadap brand switching handphone pada Mahasiswa Fakultas Ekonomi dan Bisnis Islam (FEBI) IAIN Palu.
INFORMASI ARTIKEL

\author{
Katakunci: \\ Brand switching, \\ Handphone, Mahasiswa
}




\section{PENDAHULUAN}

Dalam perkembangan lingkungan bisnis akhir-akhir ini telah memunculkan suatu gejala yang semakin banyak dan beragamnya produk yang ditawarkan oleh perusahaan pada industri yang sama. Produk yang ditawarkan dapat berupa barang atau jasa, untuk memenuhi kebutuhan hidup sehari-hari atau pemenuhan kebutuhan sekunder dan tersier. Beragamnya produk yang ditawarkan oleh perusahaan merupakan suatu strategi persaingan bisnis.

Krisis ekonomi yang sedang terjadi saat ini membuat persaingan suatu produk menjadi semakin ketat, baik di pasar domestik maupun di pasar internasional. Meskipun konsumen yang membeli selalu ada, tetapi daya belinya semakin kecil. Konsumen menjadi semakin kritis untuk melakukan pembelian atas produk yang di butuhkan, salah satunya adalah Handphone.

Di sisi perkembangan bisnisnya, Handphone akhir-akhir ini telah menunjukkan suatu gejala, yaitu semakin banyak dan beragamnya produk Handphone yang ditawarkan oleh perusahaan dan pengembangan produk Handphone yang semakin cepat. Pengembangan produk Handphone yang semakin cepat tersebut terletak pada bentuk, ukuran dan fasilitasnya. Semakin lama bentuk Handphone semakin menarik, ukurannya semakin besar dan tipis yang dilengkapi fasilitas kegunaannya semakin lengkap.

Adapun saat ini banyak merek-merek Handphone yang telah beredar di pasaran Indonesia. Berikut daftar beberap amerek Handphone yang telah beredardi pasaran Indonesia saat ini, adalah: Acer, Advan, Alcatel, Apple Iphone, Asus, Axioo, Ben q, Blackberry, Blaupunkt, Bluberry, Bold, Coolpad, Evercoss, Gionee, Himax, Htc, Huawei, Imo, Infinix, K-touch, Leagoo, Lenovo, LG, Meizu Microsoft, Mito, Motorola, Nexian, Nexcom, Nokia, Oneplus, Oppo, Polytron, Samsung, Sharp, Smartfren, Sony, Vivo, wiko Xiaomi, dan Zte. ${ }^{1}$

Dari berbagai macam merek yang di tawarkan di atas, tiap mereknya meluncurkan banyak model atau seri yang bervariasi. Strategi pengembangan produk tersebut merupakan tujuan pemasar untuk menciptakan perilaku Variety seeking pada dirikonsumen. Hal inilah yang menyebabkan para konsumen, khususnya mahasiswa FEBI (Fakultas ekonomi dan bisnis Islam) IAIN Palu sering berpindah-pindah merek dalam menggunakan handphone.

Untuk memenangkan persaingan, perusahaan harus mampu memberikan yang terbaik bagi pelanggannya, yaitu dengan memberikan kualitas yang lebih baik, produk

${ }^{1}$ http://daftar-harga-hp-androidterbaru.blogspot.com/2015/09/Daftar-Merk-HP-DIIndonesia-Paling-Lengkap.html 
yang lebi hmurah, dan pelayanan yang lebih baik. Jika pelanggan kurang puas maka kemungkinan pelanggan akan beralih kemerek lain, hal tersebut menyebabkan turunnya angka penjualan yang diikuti berkurangnya pangsa pasar (Market share) sehingga akan menurunkan laba yang dapat menimbulkan kerugian bagi perusahaan itu sendiri.

Banyak perusahaan yang telah membuktikan, bahwa oleh kuatnya strategi pengembangan produk yang dilakukan, merupakan tujuan pemasar untuk menciptakan perilaku mencari keragaman (Variety Seeking) pada konsumen merek lain. Variety Seeking adalah perilaku dari konsumen yang berusaha untuk mencari keberagaman merek di luar kebiasaannya karena tingkat keterlibatan beberapa produk rendah.

Perilaku Variety seeking disebut juga sebagai kecenderungan individu-individu untuk mencari keberagaman dalam memilih jasa atau barang pada suatu waktu yang timbul karena beberapa alasan yang berbeda. Perilaku semacam ini sering terjadi pada beberapa produk dimana tingkat keterlibatan produk itu rendah (Low Involvement). Tingkat keterlibatan produk dikatakan rendah, apabila dalam proses pembuatan keputusan konsumen tidak melibatkan banyak faktor dan informasi yang harus ikut dipertimbangkan. $^{2}$

Menurut Setyaningrum, keputusan konsumen untuk berpindah merek merupakan fenomena kompleks yang dipengaruhi oleh faktor-faktor perilaku tertentu, scenario persaingan, dan waktu, sehingga perpindahan merek tidak hanya terjadi karena faktor ketidakpuasan konsumen. Keputusan perpindahan merek yang dilakukan konsumen juga dipengaruhi oleh adanya kebutuhan mencari variasi. Kebutuhan mencari variasi merupakan komitmen secara sadar untuk membeli merek lain karena individu terdorong untuk menjadi terlibat, terdorong ingin mencobahal baru, memiliki rasa ingin tahu yang tinggi terhadap hal baru yang tujuannya adalah untuk mencari kesenangan atau untuk melepaskan kejenuhan dari merek yang biasa dipakainya. $^{3}$

Dari hasil observasi dan permasalahan di atas, penulis tertarik ingin mencari tahu apakah benar kebutuhan mencari variasi dan fitur produk berpengaruh terhadap brand switching handphone pada mahasiswa FEBI (Fakultas Ekonomi dan Bisnis Islam) IAIN Palu.

\footnotetext{
${ }^{2}$ Kahn,dkk, ManajemenPemasarandanJasa, (Bandung:Alfabeta, 1999), h 46.

${ }^{3}$ Ibid, h $2 \& 3$.
} 


\section{TINJAUAN PUSTAKA}

\subsection{Pengertian Brand Switching}

Menurut Peter dan Olson, perpindahan merek (brand switching) adalah pola pembelian yang dikarakteristikan dengan perubahan atau pergantian dari satu merek ke merek lain. Konsumen yang mengaktifkan tahap kognitifnya adalah konsumen yang paling rentan terhadap perpindahan merek karena adanya rangsangan pemasaran. ${ }^{4}, 5$ Sedangkan menurut Feiberg dkk, perpindahan merek di sini diasumsikan bahwa pelanggan tersebut menghentikan hubungan mereka dengan produsen lama untuk mencoba produk yang2.2 Faktor-Faktor yang Mempengaruhi Brand ditawarkan pesaing. ${ }^{6}$

Definisi dari brand switching lainnya menurut Sumarketer, adalah perpindahan merek yang dilakukan oleh pelanggan untuksetiap waktu penggunaan, tingkat brand switching ini juga menunjukkan sejauhmana sebuah merek

${ }^{4}$ Peter, J. P. dan Olson, J. C. 2010.Consumer Behavior and Marketing Strategy, Ninh Edition New York. McGraw Hill, h 522.

${ }^{5}$ Nurdin, N. (2016). The Roles of Information Technology in Islamic Bank Knowledge Management: A study of Two Syariah Banks in Palu. Hunafa: Jurnal Studia Islamika, 13(2), 181-217. doi: https://doi.org/10.24239/jsi.v13i2.444.181-217

${ }^{6}$ Arianto, B. A. 2011. Pengaruh Atribut Produk, Harga, Kebutuhan Mencari Variasi dan Ketidakpuasan Konsumen terhadap Keputusan Perpindahan Merek dari Samsung Galaxy Series di Kota Malang,Jurnal Aplikasi Manajemen, Vol II, No. 2, h 9. memiliki pelanggan yang loyal. ${ }^{7}$ Sedangkan menurut Ganes dkk,brand switching adalah perilaku konsumen yang mencerminkan pergantian dari merek produk yang biasa dikonsumsi dengan produk merek lain. ${ }^{8}$

Berdasarkan definisi di atas, brand switching adalah perpindahan merek yang dilakukan oleh konsumen, karena konsumen ingin mencoba produk yang baru dan lebih bagus dari merek sebelumnya.Brand switching juga dapat diartikan sebagai perilaku berpindah-pindah merek atau pergantian merek.

\section{Switching}

Menurut Rangkuti, tingkat loyalitas yang paling dasar adalah pembeli tidak loyal atau tertarik pada merek-merek apapun yang ditawarkan. Disebut konsumen Switcher atau price buyer (Konsumen lebih memperhatikan harga didalam melakukan pembelian). ${ }^{9}$ Berdasarkan definisi tersebut, salah satu faktor yang mempengaruhi konsumen dalam membeli barang karena harganya yang murah.

Menurut Irawan, dkk, perpindahan merek dapat terjadi karena adanya perilaku mencari keragaman (variety seeking)

\footnotetext{
${ }^{7}$ http://risetpemasaran.blogspot.com/2012/07/ konsep-dan-pengertian brandswitching.html.

${ }^{8}$ https://sbm.binus.ac.id/2016/06/22/penyeba b-terjadinya-brand-switching/html.

${ }^{9}$ Rangkuti, Freddy.The Power of Brand, (Jakarta PT Gramedia PustakaUtama 2002), h 61.
} 
konsumen. Konsumen yang hanya mengaktifkan tahap kognitifnya dapat dihipotesiskan sebagai konsumen paling rentan terhadap perpindahan merek karena adanya rangsangan pemasaran. Penyebab lain perpindahan merek dapat berasal dari sangat beragamnya penawaran produk lain, atau kadang-kadang karena terjadi masalah dengan produk yang dibeli. ${ }^{10}$

Menurut Agus, ada 3 faktor yang menyebabkan pelanggan untuk loyal atau melakukan perpindaha merek, yaitu: harga, ketidak puasan dan kualitas produk. ${ }^{11}$ Sedangkan menurut Dewanti, dkk, perilaku perpindahan merek pada pelanggan merupakan suatu fenomena yang kompleks $c$. dipengaruhi oleh faktor-faktor keperilakuan, persaingan, dan waktu. ${ }^{12}$

Faktor-faktor lainnya yang mempengaruhi brand switching Chatrin dan Karlina, munculnya perilaku

${ }^{10}$ Irawan, dkk, "Pengaruh Kualitas Fitur, Desain, Iklan, Kepuasan Konsumen Dan Kebutuhan Mencari Variasi Terhadap Keinginan Berpindah Merek Handpone (Survai Pada Pengguna Handphone Di Kota Purwokerto)", Universitas Jendral Soedirman Purwokerto, Jurnal Performance.Vol. 11 No.1. Maret 2010, h 83-106.

${ }^{11}$ Rahmat Agus Santoso, Analisis Perilaku Brand Switching Dalam Pembelian Produk Handphone, Jurnal Manajemen Bisnis, vol 1 No 2, 2011, h 189.

${ }^{12}$ Dewanti, dkk, 2011. "Analisis Karakteristik Produk Dan Kebutuhan Variasi Produk Dalam Mempengaruhi Perpindahan Merek Air Mineral Vit (Studi Kasus : Konsumen Vit Ukuran Galon Di Jakarta Barat)", Universitas Bina Nusantara Jakarta, h $565-578$. brand switching dipengaruhi oleh banyak faktor. Faktor-faktor tersebut antara lain $:{ }^{13}$ a. Price

Penetapan harga merupakan suatu alasan yang menyebabkan konsumen pindah ke merek yang lain, yang terdiri dari harga perbandingan, biaya, pembebanan, denda dan kesepakatan harga promosi.

\section{b. Sales Promotion}

Sales promotionadalah suatu cara untuk mempengaruhi konsumen agar langsung membeli barang dengan merek tertentu, sehingga dengan adanya sales promotion yang baik akan mempengaruhi konsumen dalam berpindah merek.

\section{c. Munculnya Produk-Produk Baru}

Munculnya pesaing-pesaing baru memang menjadi salah satu penyebab terjadinya brand switching.

\section{d. Kualitas}

Perilaku brand switching juga dipengaruhi oleh persepsi kualitas konsumen. Kualitas yang lebih baik yang ditawarkan suatu produk baru atau lain dapat mempengaruhi konsumen untuk berpindah dari suatu produk yang satu ke produk yang lain.

Menurut Wuri, terdapat 2 faktor yang mempengaruhi terjadinya brand switching yaitu faktor internal dan faktor eksternal konsumen $::^{14}$

\footnotetext{
${ }^{13}$ Alens Diana Mantansari, dkk, h 6.

${ }^{14}$ Ibid, h 7.
} 


\section{a. Faktor Internal Konsumen}

Faktor internal adalah faktor lingkungan dari dalam diri konsumen.Dimensi faktor internal konsumen adalah keinginan untuk mencari variasi, dissatisfaction, dan pengetahuan konsumen mengenai merek.

\section{b. Faktor Eksternal Konsumen}

Faktor eksternal adalah faktor lingkungan dari konsumen yang dapat mempengaruhi perpindahan merek baik berupa iklan, promosi dan sebagainya.

David Aaker membuat urutan loyalitas merek dalam lima tingkatan, yaitu: ${ }^{15}$

1. Switcher, adalah pembeli yang sama sekali tidak loyal. Pembeli yang tidak mau terikat sama sekali dengan merek apa pun. Merek mempunyai peranan kecil dalam keputusan pembeli jenis ini.

2. Habitual buyer, adalah pembeli yang merasa puas dengan produk atau paling tidak mereka tidak kecewa. Pembeli ini memilih merek karena kebiasaan saja.

3. Satisfied buyer with switching cost, yaitu pembeli yang merasa puas (satisfied buyer) dengan menanggung atau mengeluarkan biaya peralihan (switching cost), seperti biaya, waktu, uang, dan risiko pemakaian karena pengalihan merek.

${ }^{15} \mathrm{http}$ ://ekonomi.kabo.biz/2012/01/perpindah an-merek-brand-switching.html.
4. Liking the brand, yaitu tipe pembeli yang sangat menyukai merek, pembeliannya berdasarkan asosiasi merek (mungkin simbol atau karena rangkaian pengalaman menggunakan sudah lama).

5. Commited buyer, mereka ini adalah pembelipelanggan yang sangat setia. Mereka sangat bangga dalam menggunakan merek tertentu itu. Merek sangat penting bagi pembeli karena functional benefit dan emotional benefit mampu mengekspresikan jati dirinya. Inilah sebetulnya puncak usaha perusahaan membangun merek (meningkatkan, memelihara, dan inovasi konsisten). Perusahaan telah mampu menjadikan brandnya sebagai brand advantage (merek unggul) sehingga mendorong banyaknya commited buyer (pembeli yang komitmen, tidak mau berpindah merek).

\subsection{Variety Seeking}

a. Pengertian Variety seeking

Menurut Peter dan Olson, pencarian variasi merupakan komitmen kognitif untuk membeli merek yang berbeda, yang disebabkan adanya stimulasi keterlibatan sesuatu dalam mencoba sesuatu yang berbeda, keinginan baru atau timbulnya rasa bosan pada sesuatu yang telah lama dikonsumsi. ${ }^{16}$ Sedangkan menurut Emelia tujuan lain perilaku mencari variasi dapat

${ }^{16}$ Peter, J. P. dan Olson, J.C, Consumer Behavior and Marketing Strategy, h 76. 
berupa hanya sekedar mencoba sesuatu yang baru atau mencari suatu kebaruan dari sebuah produk. ${ }^{17}$

b. Hubungan Variety Seeking dan Brand Switching

Kecenderungan pada diri konsumen yang hanya ingin mencoba-coba atau mencari sesuatu yang baru, menjadi perhatian para pemasar akan keberhasilan produk yang ditawarkan. Mengidentifikasi konsumen yang suka mencari variasi merupakan salah satu hal yang penting bagi perusahaan karena perilaku perpindahan merek (brand switching) dapat muncul karena adanya kebutuhan mencari variasi (variety seeking).

Menurut Schiffman dan Kanuk terdapat beberapa tipe konsumen yang mencari variasi (variety seeking) $:^{18}$

1) Perilaku Pembelian yang bersifat penyelidikan (Explanatory Purchase Behavior), merupakan keputusan perpindahan merek untuk mendapatkan pengalaman baru dan kemungkinan alternatif yang lebih baik.

2) Penyelidikan pengalaman orang lain (Vicarious Exploration), yaitu konsumen mencari informasi tentang suatu produk

${ }^{17}$ Emelia, S. 2012. Pengaruh Atribut Produk, Kepuasan, dan variety seeking terhadap Brand Switching konsumen Rinso ke Merek lain di kota Padang. Thesis. Universitas Sumatera Utara, h 12.

${ }^{18}$ Schiffman, L.G. and L.L. Kanuk, Consumer Behavior, Tenth Edition. (New Jersey: Pearson International Edition 2010), h 126. yang baru atau alternatif yang berbeda, kemudian mencoba menggunakannya.

3) Keinovatifan Pemakaian (Use Innovativeness), konsumen telah menggunakan dan mengadopsi suatu produk dengan mencari produk yang lebih baru dengan teknologi yang lebih tinggi.

Dengan demikian, maka konsumen akan sering mengekspresikan kepuasan dengan merek barang seperti yang mereka gunakan sekarang, tetapi tetap terlibat dalam penggantian merek. Hal ini dapat terjadi karena pencarian variasi adalah motif konsumen yang cukup lazim. Konsumen yang mempunyai keterlibatan emosional yang rendah terhadap suatu merek akan mudah berpindah pada merek pesaing. Kecenderungan inilah yang sering menjadi perhatian para pemasar akan keberhasilan produk yang ditawarkan. Kebutuhan mencari variasi (variety seeking) adalah suatu hal yang dimiliki oleh sebagian konsumen.

3 Fitur produk

Kita tentu sering mendengar istilah fitur, yang sebenarnya diserap dari bahasa asing (Inggris) feature. Adapun arti kata feature dalam bahasa inggris adalah "featureis a prominent or distinctive aspect, quality, or characteristic". Fitu adalah aspek, kualitas atau ciri yang menonjol. Arti feature lainnya adalah "feature is a special 
attraction". feature adalah daya tarik khusus. ${ }^{19}$

Fitur adalah alat persaingan untuk membedakan produk perusahaan terhadap produk sejenis yang menjadi pesaingnya. Menjadi produsen awal yang mengenalkan fitur baru yang dibutuhkan dan dianggap bernilai menjadi salah satu cara yang efektif untuk bersaing. ${ }^{20}$

Menurut Armstrong dan Kotler, fitur produk yaitu alat persaingan untuk membedakan produk perusahaan terhadap produk sejenis yang menjadi pesaingnya.Dengan berbagai fitur produk yang ditawarkan oleh produsen, konsumen akan semakin terpuaskan dengan produkproduk yang sesuai dengan kebutuhannya guna mendiferensiasi produk yang dihasilkan oleh perusahaan terhadap produk sejenis yang dihasilkan perusahaan lain diperlukan suatu alat yang dapat menjadi nilai tambah bagi konsumen untuk dapat memilih produk tersebut, alat tersebut salah 4 satunya dengan menggunakan fitur yang ada dalamproduk tersebut. ${ }^{21}$

Menurut Cravens, fitur juga dapat digunakan sebagai sarana untuk

\footnotetext{
${ }^{19}$ http://saynotogaptek.blogspot.com/2012/03 /apa-itu-fitur-dalam-istilah-teknologi.html

${ }^{20} \mathrm{http}: / /$ www.pendidikanekonomi.com/2012/ 07/pengertian-dan-manfaat-atribut produk.html

${ }^{21}$ Siti Hamidah dan Desi Anita, Analisis Persepsi Citra Merek, Desain, Fitur Dan Pengaruhnya Terhadap Keputusan Pembelian Produk Handphone Samsung Berbasis Android (Studi Kasus Stie Pelita Indonesia,(Jurnal Ekonomi Volume 21, Nomor 4 Desember 2013), h 7.
}

membedakan suatu merek dari pesaingnya. ${ }^{22}$ Sedangkan Fandy Tjiptono mengatakan bahwa fitur adalah unsur-unsur produk yang dipandang penting oleh konsumen dan dijadikan dasar pengambilan keputusan pembelian. Fitur produk dapat mempengaruhi keputusan konsumen untuk membeli suatu produk, karena fitur produk melekat erat pada suatu produk dan seringkali digunakan oleh konsumen sebagai dasar dan pertimbangan untuk memutuskan membeli atau tidak suatu barang atau jasa yang ditawarkan. ${ }^{23}$

Adapun yang dimaksud dengan fitur produk dalam penelitian ini, adalah layanan atau aplikasi yang ditwarkan oleh produsen handphone kepada konsumennya.Seperti : Game, Line, Whatsapp, kamera, dll, inilah yang disebut sebagai fitur produk di dalam handphoe tersebut, yang menyebabkan konsumen (mahasiswa) dalam melakukan perpindahan merek handphone.

\section{Perilaku Konsumen}

Perilaku konsumen adalah tingkah laku dari konsumen, dimana merekadapat mengilustrasikan pencarian untuk membeli, menggunakan, mengevaluasidan memperbaiki suatu produk dan jasa

\footnotetext{
${ }^{22}$ https://bonteng.wordpress.com/2009/11/16/ atribut-produk/html

${ }^{23}$ Aditya Yesika, dkk, Pengaruh Citra Merek, Desain, dan Fitur Produk terhadap Keputusan Pembelian Handphone Nokia (Studi Kasus pada Mahasiswa Universitas Diponegoro), Jurnal ekonomi, h 4.
} 
mereka.Fokus dari perilaku konsumenadalah bagaimana individu membuat keputusan untuk menggunakan sumberdaya mereka yang telah tersedia untuk mengkonsumsi suatu barang.

Rasionalnya konsumen akan memuaskan konsumsinya sesuai dengankemampuan barang dan jasa yang dikonsumsi serta kemampuan konsumen untukmendapatkan barang dan jasa tersebut. Dengan demikian kepuasan dan prilakukonsumen dipengaruhi oleh hal-hak sebagai berikut $:^{24}$

a) Nilai guna (utility) barang dan jasa yang dikonsumsi. Kemampuan barang danjasa untuk memuaskan kebutuhan dan keinginan konsumen.

b) Kemampuan konsumen untuk mendapatkan barang dan jasa. Daya beli dariincome konsumen dan ketersediaan barang dipasar.

c) Kecenderungan konsumen dalam menentukan pilihan konsumsi menyangkut pengalaman masa lalu, budaya, selera, serta nilai-nilai yang dianut sepertiagama, adat istiadat.

Adapun faktor-faktor yang mempengaruhi perilaku konsumen dalam

\footnotetext{
${ }^{24}$ http://Hendrakholid.Net/Blog/2010/04/06/P rilaku-Konsumen-Dan-Teori-Konsumsi-DalamIslam/,
}

melakukan pembelian maupun menggunakan suatu produk antara lain: ${ }^{25}$

a. Faktor budaya

Kebudayaan adalah faktor penentu yang paling dasar dalam perilaku pengambilan keputusan dan perilaku pembelian. Kebudayaan didefinisikan sebagai kompleks simbol dan barang-barang buatan manusia (artifacts) yang diciptakan oleh masyarakat tertentu dan diwariskan dari generasi yang lain sebagai faktor penentu (determinants) dan pengatur (regulator) perilaku anggotanya. Jadi, dari paparan di atas dapat disimpulkan bahwa budaya adalah segala nilai, pemikiran, simbol yang mempengaruhi perilaku, sikap, kepercayaan dan kebiasaan seseorang dan masyarakat.

\section{b. Faktor sosial}

Faktor sosial merupakan faktor penting yang mempengaruhi perilaku konsumen ${ }^{26}$. Faktor-faktor sosial yang dapat mempengaruhi perilaku konsumen adalah keluarga dan kelompok acuan, sebagaimana dijelaskan sebagai berikut:

1) Keluarga

Keluarga adalah lingkungan mikro, yaitu lingkungan yang paling dekat

${ }^{25}$ Anita Rahmawati, Perilaku Konsumen dalam Ekonomi Islam, (Yogyakarta: Idea Press 2011), h 17.

${ }^{26}$ Nurdin, N., Novia, N., Rahman, A., \& Suhada, R. (2019). Potensi Industri Produk Makanan Halal Di Kota Palu. Jurnal Ilmu Ekonomi dan Bisnis Islam, 1(1), 1-12. 
konsumen. Keluarga menjadi daya tarik bagi para pemasar karena keluarga memiliki pengaruh yang besar kepada konsumen.

2) Kelompok acuan (reference group)

Kelompok acuan (reference group) adalah seorang individu atau sekelompok orang yang secara nyata mempengaruhi perilaku seseorang.Kelompok acuan digunakan oleh seseorang sebagai dasar untuk perbandingan atau sebuah referensi dalam membentuk respon efektif, kognitif dan perilaku.Dalam perspektif pemasaran, kelompok acuan adalah kelompok yang berfungsi sebagai referensi bagi seseorang dalam keputusan pembelian dan konsumsi.

c. Faktor kepribadian

Kepribadian merupakan faktor penting yang mempengaruhi perilaku konsumen. Perbedaan kepribadian akan mempengaruhi perilaku seseorang dalam memilih atau membeli produk karena konsumen akan membeli barang yang sesuai 1. dengan kepribadianya.

\subsection{Perilaku Konsumen dalam Islam}

Perilaku konsumen di dalam islam sama halnya dengan perilaku konsumen pada umumnya, hanya saja islam membatasi para konsumennya dalam melakukan proses dan aktivitas yang berhubungan dengan pencarian, pemilihan, pembelian, pnggunaan, serta pengevaluasian produk dan jasa untuk memenuhi kebutuhan dan keinginan agar sikap dan perilaku konsumen mengikuti aturan-aturan yang ditetapkan dalam Islam.

Berbeda dengan konsumen konvensional, seorang muslim dalam penggunaan penghasilanya memiliki dua sisi, yaitu pertama untuk memenuhi kebutuhan diri dan keluarganya dan sebagiannya lagi untuk dibelanjakan di jalan Allah

Dalam Islam, perilaku seorang konsumen harus mencerminkan hubungan dirinya dengan Allah Swt. Inilah yang kita tidak temukan dalam ilmu perilaku konsumsi konvensional. Setiap pergerakan dirinya, yang berbentuk belanja sehari -hari, tidak lain adalah manifestasi zikir dirinya atas nama Allah dengan tidakmemilih barang yang haram, tidak kikir, dan tidak tamak supaya hidupnya selamat baik di dunia maupun di akhirat.

\section{. Konsumsi dalam Islam}

Dalam Islam, konsumsi tidak dapat dipisahkan dari peranan keimanan. Peranan keimanan menjadi tolak ukur penting karena keimanan memberikan cara pandang dunia yang cenderung mempengaruhi kepribadian manusia. Keimanan sangat mempengaruhi kuantitas dan kualitas konsumsi baik dalam bentuk kepuasan material maupun spiritual.

Menurut Manan, "Dalam Ekonomi Islam, konsumsi diakui sebagai salah satu perilaku ekonomi dan kebutuhan asasi dalam 
kehidupan manusia.Perilaku konsumsi diartikan sebagai setiap perilaku seorang konsumen untuk menggunakan dan memanfaatkan barang dan jasa untuk memenuhi kebutuhan hidupnya.Namun Islam memberikan penekanan bahwa fungsi perilaku konsumsi adalah untuk memenuhi kebutuhan manusia baik jasmani dan ruhani sehingga mampu memaksimalkan fungsi kemanusiaannya sebagai hamba dan khalifah Allah untuk mendapatkan kebahagiaan dunia dan akherat". ${ }^{27}$

Imam Syatibi mengatakan bahwa tanggung jawab syariah adalah untuk menjaga maqasid syar'iyyah. Tanggung jawab ini juga berkaitan dengan perilaku konsumsi yang harus diperhatikan oleh setiap muslim dalam kehidupannya. Tanggung jawab ini terdiri dari 3 bagian, yaitu: ${ }^{28}$

a. Dharuriyah

Dharuriyah, ialah sesuatu yang harus ada dalam menegakkan maslahatagama dan dunia, jika tidak ada maka tidaklah akan tegak maslahattersebut secara benar, bahkan akan rusak, hancur dan hilang darikehidupan bahkan selanjutnya juga nanti di akhirat akan menimbulkan kerugian yang nyata. Adapun

\footnotetext{
${ }^{27}$ Mannan, Teori dan Praktek Ekonomi Islam, (Yogyakarta:Dana Bhakti Prima Yasa, 1997), h 44

${ }^{28}$ Syatibi.Al-Muwafaqat fi Ushul alSyariah.Jilid.2 (Bairut: Dar al-Kutub al-Ilmiyah.tt) h.7.
}

yang termasuk dharuriyat al-Khamsitersebut adalah :

1) Menjaga agama.

2) Menjaga jiwa.

3) Menjaga akal.

4) Menjaga keturunan atau kehormatan dan

5) Menjaga harta.

Dalam hal konsumsi juga seseorang dilarang melakukan konsumsiyang membahayakan hal yang lima di atas.

b. Hajjiyah

$$
\text { Al-Hajiyyah (sekunder), adalah }
$$
segala sesuatu yang oleh hokum syara' tidak dimaksudkan untuk memelihara lima hal pokok keperluanmanusia di atas, akan tetapi dimaksudkan untuk menghilangkankesempitan (musyaqat) atau berhati-hati (ihtiyah) terhadap lima haltersebut. Hajiyyat dalam kaitannya dengan konsumsi, seperti diharamkannya kikir, mubazir dan boros, karena walaupun tidak menyebabkan lenyapnya harta, tetapi maksudnya adalah menghilangkan kesempitan dalam penegakan hal lima di atas. Begitu juga, peminjam yangmampu, yang tidak mau membayar hutangnya. Sedangkan hajiyyat berkaitan dengan akal seperti diharamkannya meminum sedikit minumankeras, yang juga berkaitan dengan perilaku konsumsi .Dan hal yanghajjiyyat adalah sesuatu yang diperlukan oleh manusia untuk kelapangandan keleluasaan, menanggung beban taklif, dan beban 
kehidupan lainnya.Apabila sesuatu itu tidak ada, maka tidak akan merusak strukturkehidupan mereka, dan kekacauan tidak akan merajalela.

c. Tahsiniyah.

$$
\text { Al-tahsiniyah (pelengkap) adalah }
$$
tindakan dan sifat yang harusdijauhi oleh akal yang sehat, dipegangi oleh adat kebiasaan yang bagus dan dihajati oleh kepribadian yang kuat. Itu semua termasuk bagian akhlaqkarimah, sopan santun dan adab untuk menuju ke arah kesempurnaan.Artinya hal ini tidak dapat dipenuhi, maka kehidupan manusia tidaklah sekacau sekiranya urusan duniawiyah tidak diwujudkan dan tidak membawa kesusahan dan kesulitan seperti tidak dipenuhinya urusanhajiyah manusia. Akan tetapi, hanya di anggap kurang harmonis oleh pertimbangan nalar sehat dan suatu hati nurani.Urusan tahsiniyah dalam konsumsi bisa dengan memberikan sedekah kepada orang yang sangat membutuhkan, sebagai bentuk kepedulian, bersopan santun dalam melakukan makan dan minum, konsumsi segala sesuatu yang bersih, tidak mengandung penyakit, dan lain-lain.

Dalam perspektif Islam, antara benda $b$. ekonomi yang satu dengan yang lainnya bukan merupakan subsidi yang sempurna. Terdapat benda yang lebih berharga dan bernilai dan benda ekonomi yang kurang bernilai bahkan terlarng sehingga akan dijauhi. Selain itu juga terdapat prioritas dalam pemenuhannya berdasarkan tingkat kemaslahatan yang dibutuhkan untuk menunjang kehidupan yang Islami. Preperensi konsumsi tersebut adalah: ${ }^{29}$

a. Mengutamakan akhirat dari pada dunia

Pada dasarnya seorang muslim akan dihadapkan kepada pilihandiantara mengkonsumsi benda ekonomi yang bersifat duniawi belaka danyang bersifat ibadah. Konsumsi untuk ibadah bernilai lebih tinggi karenaorientasinya falah dan kehidupan diakhirat kelak. Semakin besar konsumsiuntuk ibadah maka semakin tinggi pula falah yang akan dicapai, sebaliknyasemakin besar konsumsi duniawi terhadap konsumsi untuk ibadah maka akansemakin rendah fallah yang dicapai. Seorang muslim yang rasional, yaituorang yang beriman, semestinya akan mengalokasikan anggaran lebih banyakdalam konsumi untuk ibadah dibandingkan dengan konsumsi duniawi. Allah memperkenankan hambanya untuk menkmati kekayaan dunia sebagai wujudsyukur kepada-Nya dan sekaligus sebagai sarana untuk mendukung ibadah.

b. Konsisten dalam prioritas pemenuhannya Kebutuhan manusia dalam konsumsi sebenarnya memiliki tingkaturgensi yang selalu sama. Terdapat prioritas-prioritas

\footnotetext{
${ }^{29}$ Hendrie Anto, Pengantar Ekonomika Makro Islami, Terjemahan, (Yogyakarta: Ekonosia,2003), Cet.I, h 129
} 
diantara satu denganyang lainnya yang menunjukkan tingkat kemanfaatan dan kemendesakandalam pemenuhannya.Para ulama telah membagi prioritas ini menjadi,daruriyyah, hajjiyah, dan tahsiniyah.

Memperhatikan etika dan norma Syariat Islam memiliki seperangkat etika dan norma yang harus dipegang manakala seseorang berkonsumsi. Beberapa etika tersebut diantaanyakesederhanaan, keadilan, kebersihan, halalan tayyiban, keseimbangan danlain-lain.

\section{B. Hipotesis}

Hipotesis merupakan pernyataan sementara yang perlu dibuktikan benar atau tidak. ${ }^{30}$ Berdasarkan latar belakang dan masalah yang dikemukakan maka hipotesis yang digunakan dalam penelitian ini adalah :

1. $\mathrm{H}_{1}$ : diduga variety seeking dan fitur produk secara serempak berpengaruh signifikan terhadap brand switchinghandphone pada mahasiswa jurusan Ekonomi FEBIIAIN Palu.

2. $\mathrm{H}_{2}$ : diduga variety seeking berpengaruh signifikan terhadap brand switchinghandphone pada mahasiswa jurusan Ekonomi FEBI IAIN Palu.

3. $\mathrm{H}_{3}$ : diduga fitur produk berpengaruh signifikan terhadap brand switching

${ }^{30}$ Husein Umar, Metode Riset Perilaku konsumen Jasa, (Jakarta: Ghalia Indonesia, 2003), h 61. handphone pada mahasiswa jurusan EkonomiFEBI IAIN Palu.

\section{METODE PENELITIAN}

Penelitian ini menggunakan pendekatan kualitatif ${ }^{31}$ dengan pendekatan survey $^{32}$. Kegiatan penelitian meliputi data, analisis, dan interpretasi tetang arti dari data yang diperoleh, instrument penelitian ini menggunakan kuesioner. Penelitian ini juga dimaksud untuk mengetahui pengaruh pendidikan dan pekerjaan terhadap kemiskinan di Kecamatan Bolano Kabupaten Parigi Moutong.

Sampel dari penelitian ini adalah mahasiswa Fakultas Ekonomi dan Bisnis Islam semester 5 dan 6 yang dipilih secara acak 80 orang. Teknik pengambilan sampel purposive sampling. Teknik analisis data yang digunakan adalah analisis regresi linear berganda dan analisis residual.

Alat ukur dalam penelitian biasanya dinamakan instrument penelitian. Jadi instrumen penelitian ini adalah suatu alat yang digunakan mengukur fenomena alam

\footnotetext{
${ }^{31}$ Miller, K. (2001). Quantitative Research Method in The New Hanbook of Organziational Communication: Advances in Theory, Research and Methods by frederick M. Jablin and Linda L. Putnam (Editors), London : Sage Publications.

${ }^{32}$ Boose, J. H. (1989). A survey of knowledge acquisition techniques and tools. Knowledge Acquisition, 1(1), 3-37. doi: https://doi.org/10.1016/S1042-8143(89)80003-2
} 
maupun sosial yang diamati. ${ }^{33}$ Karena instrumen penelitinan akan digunakan untuk melakukan pengukuran dengan tujuan menghasilkan data kuantitatif yang akurat, maka setiap instrumen harus mempunyai skala. Penelitian ini menggunakan skala likert. Data diolah dengan menggunakan aplikasi statistic SPSS.

\section{HASIL DAN PEMBAHASAN}

\subsection{Deskrpsi Responden}

Deskripsi responden digunakan untuk menggambarkan keadaan atau kondisi responden sehingga dapat memberikan informasi tambahan serta memahami hasil- a. hasil penelitian. Penyajian data deskripsi penelitian bertujuan agar dapat dilihat dari data penelitian tersebut serta hubungan anatara variabel yang digunakan dalam penelitian dengan jumlah responden.

a. Deskrpis responden berdasarkan jenis kelamin

Jenis kelamin merupakan perbedaan bentuk, sifat, dan fungsi biologi laki-laki dan perempuan yang menentukan perbedaan peran mereka dalam upaya menyelenggarakan upaya meneruskan garis keturunan. Adapun karakteristik responden

\footnotetext{
${ }^{33}$ Sugiyono, Metode Penelitian Kombinasi, (Bandung: CV Alfabeta, 2015), h.136.
}

berdasarkan jenis kelamin dapat dilihat pada tabel 1 berikut ini :

Tabel 1. Karakteristik Respondent

\begin{tabular}{|l|c|c|c|}
\hline No & $\begin{array}{c}\text { Jenis } \\
\text { Kelamin }\end{array}$ & $\begin{array}{c}\text { Jumlah } \\
\text { (Orang) }\end{array}$ & $\begin{array}{c}\text { Persentase } \\
(\mathbf{\%})\end{array}$ \\
\hline 1 & Laki-laki & 32 & 40 \\
\hline 2 & Perempuan & 48 & 60 \\
\hline \multicolumn{2}{|c|}{ Total } & $\mathbf{8 0}$ & $\mathbf{1 0 0}$ \\
\hline
\end{tabular}

Sumber: Daftar pemyataan diolah, Juni 2019.

Berdasarkan tabel, dapat dijelaskan bahwa sebagian besar yang menjadi responden adalah laki-laki yang berjumlah 32 orang dengan persentase sebesar (40\%), sedangkan sisanya merupakan responden perempuan berjumlah 48 orang dengan persentase $(60 \%)$.

Deskripsi responden berdasarkan jenis merek

Merek merupakan suatu nama, simbol, tanda, desain atau gabungan diantaranya untuk dipakai sebagai identitas suatu perorangan, organisasi atau perusahaan pada barang dan jasa yang dimiliki untuk membedakan dengan produk jasa lainnya.

Dari jumlah keseluruhan 80 responden yang disebar, rata-rata merek yang digunakan mahasiswa FEBI IAIN Palu, diantaranya adalah: Samsung yang berjumlah 26 responden dengan persentase $32.5 \%$, Xiaomi sebanyak 18 responden dengan persentase $22.5 \%$, Oppo sebanyak 12 responden dengan persentase 15\%, Vivo sebanyak 14 responden dengan persentase $17.5 \%$ dan merek lain sebanyak 10 
responden dengan persentase $12.5 \%$. Adapun perincian karakeristik responden berdasarkan Jenis Merek dapat dilihat pada tabel 2 berikut:

Tabel 2. Merek HP yang digunakan

\begin{tabular}{|l|l|c|c|}
\hline NO & Jenis Merek & $\begin{array}{c}\text { Jumlah } \\
\text { (Merek) }\end{array}$ & $\begin{array}{c}\text { Persentase } \\
(\mathbf{\%})\end{array}$ \\
\hline 1 & Samsung & 26 & 32.5 \\
\hline 2 & Xiaomi & 18 & 22.5 \\
\hline 3 & Vivo & 14 & 17.5 \\
\hline 4 & Oppo & 12 & 15 \\
\hline 5 & Merek lain & 10 & 12.5 \\
\hline \multicolumn{2}{|c|}{ Total } & $\mathbf{8 0}$ & $\mathbf{1 0 0}$ \\
\hline
\end{tabular}

Sumber: Daftar pemyataan diolah, Juni 2019.

Berdasarkan tabel di atas, bahwa merek rata-rata merek yang digunakan mahasiswa adalah: Samsung, Xiaomi, Oppo, Vivo dan merek lainnya. Dari merek tersebut, yang paling banyak digemari mahasiwa atau menempati posisi pertama adalah Samsung dengan persentase 32.5\%, yang kemudian disusul oleh Xiaomi di posisi ke-dua dengan persentase $22.5 \%$, yang kemudian disusul oleh Vivo menempati $b$. posisi ke-tiga dengan persentase $17.5 \%$, Oppo pada posisi ke-empat dengan jumlah persentase $15 \%$, dan diikuti oleh merek lainnya yang berada diposisi terendah dengan persentase $12.5 \%$.

\subsection{Hasil Uji Instrumen}

a. Uji Validitas

Uji validitas yaitu mengkorelasikan masing-masing pernyataan dengan jumlah skor untuk masing-masing variabel. Syarat minimum untuk memenuhi syarat adalah apabila $\mathrm{r}=0,3$ jadi apabila korelasi antar butir dengan skor total kurang dari 0,3 maka instrumen tersebut tidak valid. ${ }^{34}$

Tabel 3. Hasil Uji Validitas

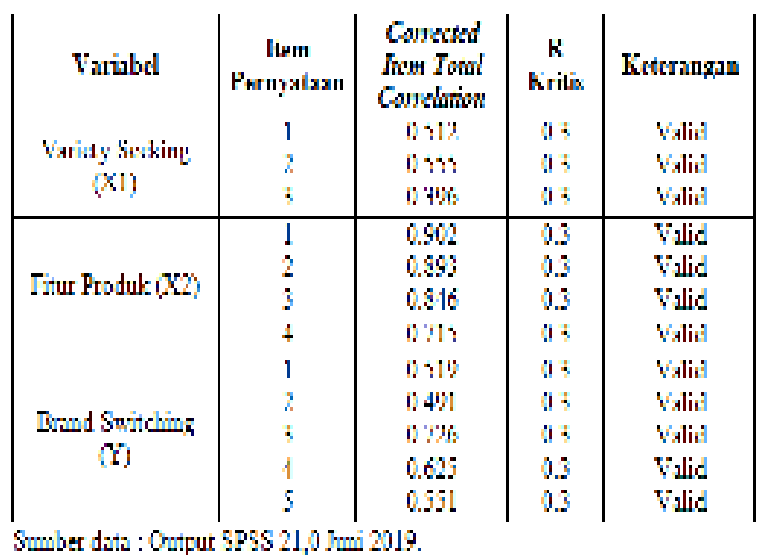

Dari tabel 4.6 menunjukkan bahwa nilai r ritung pada kolom Corrected Item Total Correlation untuk masing-masing item memiliki $\mathrm{r}_{\text {hitung }}$ lebih besar dan positif dari 0,3 yang artinya item pernyataan dalam variabel $\mathrm{X} 1$,dan $\mathrm{X} 2$ dan $\mathrm{Y}$ adalah valid. Sehingga pernyataan kuesioner yang dinyatakan valid dapat digunakan dalam pengumpulan data penelitian.

b. Uji Reliabilitas

Pengujian reliabilitas dilakukan dengan internal consistensy atau derajat ketepatan jawaban. Untuk penelitian ini digunakan Statistical Packaged For social Sciences (SPSS) sebagai alternatif pengujian reliabilitas untuk mengetahui konsistensi hasil sebuah jawaban tentang tanggapan responden. Untuk melakukan pengujian reliabititas penulis menggunakan SPSS versi

${ }^{34}$ Sugiyono, Metode Penelitian Kuantitatif, Kualitatif dan $R$ an D, (Cet.XIII; Bandung: CV. Alfabeta, 2011), h 20. 
21.0, yaitu dalam mengukur reliabilitas disini menggunakan uji statistik Cronbach Alpha $(\alpha)$, yang mana satu variabel dikatakan reliabel jika memiliki Cronbach Alpha lebih dari $0,60(>0,60) .{ }^{35}$

Instrumen yang sudah dipercaya, yang reliabel, akan menghasilkan data yang dapat dipercaya pula. Apabila datanya memang sesuai dengan kenyataanya, maka berapa kalipun diambil tetap akan sama. Alat ukur itu reliabel bila alat itu dalam mengukur suatu gejala pada waktu yang berlainan senantiasa menunjukan hasil yang sama.

Hasil pengujian reliabilitas instrumen menggunakan alat bantu oleh statistik SPSS versi 21.0 for windows dapat diketahui dalam tabel berikut:

Tabel 4. Hasil Uji Reliabilitas

\begin{tabular}{|l|c|c|c|}
\hline \multicolumn{1}{|c|}{ Variabel } & $\begin{array}{c}\text { Reliability } \\
\text { Coeficiens }\end{array}$ & $\begin{array}{c}\text { Cronbach } \\
\text { Alpha }\end{array}$ & Keterangan \\
\hline $\begin{array}{l}\text { Variety } \\
\text { Seekinng (X1) }\end{array}$ & 3 Item & 0.670 & Reliabel \\
\hline $\begin{array}{l}\text { Fitur Produk } \\
(\mathrm{X} 2)\end{array}$ & 4 Item & 0.930 & Reliabel \\
\hline $\begin{array}{l}\text { Brand Switching } \\
\text { (Y) }\end{array}$ & 5 Item & 0.799 & Reliabel \\
\hline
\end{tabular}

Sumber data : Output SPSS 21,0 Juni 2019.

\subsection{Hasil Uji Hipotesis}

a. Uji T (Parsial)

Uji hipotsis dilakukan dengan Uji T (parsial) digunakan untuk menguji apakah sebuah variabel independen (variety seeking dan fitur produk) benar-benar memberikan kontribusi terhadap variabel dependen (brand switching handphone). Berikut di

\footnotetext{
${ }^{35}$ Ibid, h 56.
}

bawah ini tabel hasil uji $\mathrm{T}$ pada tabel coeficients.

Tabel 5. Hasil Uji T (Parsial)

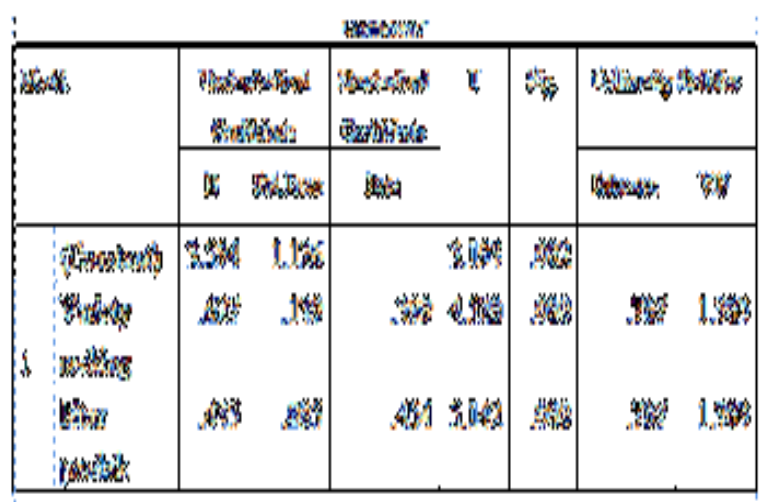

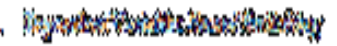

Berdasarkan hasil perhitungan statistik uji $\mathrm{T}$ dari 2 variabel independen yang dimasukkan dalam model regresi terlihat bahwa:

1. Variety seeking (X1) diperoleh nila thitung $4.520>t_{\text {tabel }} 1,991$ dan memilki nilai signifikan (sig) 0,000 pada tabel coefficients dengan nilai $\alpha$ (tingkat siginfikan) 0,05. Artinya $0,000<0,05$. Dengan nilai ini memberikan makna bahwa secara parsial variabel Variety seeking (X1) memberikan pengaruh secara siginfikan terhadap brand switching handphone (Y).

2. Fitur produk (X2) diperoleh nilai $t$ hitung $5.142>t_{\text {tabel }} 1,991$ dan nilai signifikan (sig) 0,00 lebih kecildari nilai $\alpha 0,05$. Artinya $0,00<0,05$. Dengan nilai ini memberikan makna bahwa variabel fitur produk(X2) memberikan pengaruh yang signifikan terhadap brand switching handphone (Y). 
b. Uji F (Simultan)

Pengujian ini ingin diketahui apakah variabel independen $(\mathrm{X})$ berpengaruh secara bersama-sama memberikan kontribusi secara signifikan terhadap variabel dependen $(\mathrm{Y})$.

Tabel 5. Hasil Uji Simultan

\begin{tabular}{|c|c|c|c|c|c|c|}
\hline \multicolumn{7}{|c|}{ ANOVA $^{\mathrm{B}}$} \\
\hline \multicolumn{2}{|c|}{ Model } & Sum of & Df & Mean & $\mathrm{F}$ & Sig. \\
\hline \multirow{3}{*}{1} & Regression & 340.237 & 2 & 170.119 & 45.146 & $.000^{\circ}$ \\
\hline & Residual & 290.150 & 77 & 3.768 & & \\
\hline & Total & 630.387 & 79 & & & \\
\hline
\end{tabular}

a. DependentVariable: BRAND SWITCHING

b. Predictors: (Constant), FITUR PRODUK, VARIETY SEEKING

Berdasarkan hasil uji Anova (Analisis Of Varians), atau $\mathrm{F}$ tes diperoleh nilai $F_{\text {hitung }}$ sebesar $45.146>F_{\text {tabel }} 2.718$ dengan nilai Sig sebesar 0,000 lebih kecil dibandingkan alpha $(\alpha) \quad 0,05$. Dengan demikian hasil ini memberikan makna bahwa variabel variety seeking (X1) dan fitur produk (X2) secara simultan berpengaruh signifikan terhadap brand switching handphone (Y).

\subsection{Pembahasan}

Dari hasil pengujian hipotesis yang dilakukan, H1, H2 dan H3 dapat diterima. Hal ini menunjukan bahwa pengaruh berbagai faktor yang terdiri dari variety seeking dan fitur produk secara parsial dan simultan memiliki pengaruh yang signifikan terhadap brand switching handphone pada mahasiswa FEBI IAIN PALU. Sumbangan pengaruh berbagai faktor terhadap brand switching handphone pada mahasiswa FEBI IAIN PALU dapat dilihat dari nilai koefisien determinasi $\left(\mathrm{R}^{2}\right)$. Berdasarkan hasil perhitungan diperoleh nilai $\mathrm{R}^{2}$ sebesar 0.540 yang artinya pengaruh berbagai faktor (variety seeking dan fitur produk) hanya memberikan pengaruh sebesar 54\% terhadap brand switching handphone pada mahasiswa FEBI IAIN PALU, sedangkan sisanya 46\% dipengaruhi oleh faktor yang tidak dijelaskan dalam penelitian ini.

Temuan hasil penelitian ini sejalan dengan pendapat para peneliti terdahulu yaitu penelitian yang dilakukan oleh Anjas Asmara, Sri Rosari Sitomorang, Aditya Yesika Alana dan Setyo Ferry Wibowo tentang yang secara bersama-sama meneliti tentang faktor-faktor yang mempengaruhi brand switching handphone. Hanya saja yang membedakan penelitian ini dari para peneliti terdahulu yang menjadi rujukan peneliti yaitu: waktu, tempat, teknik pengambilan sampel, variabel dari faktorfaktor yang mempengaruhi brand switching handphone, dan pandangan ekonomi islam tentang brand switching handphone. Karena dalam penelitian ini peneliti membahas pandangan ekonomi islam terhadap brand switching handphone, berbicara tentang brand switching tentunya berbicara tentang sikap atau perilaku seseorang yang selalu melakukan proses berpindah-pindah merek dalam melakukan konsumsinya. Sedangkan 
dalam islam, konsumsi tidak dapat minat (Y). Dengan nilai signifikan $0.000<$ dipisahkan dari peranan keimanan.

0.05 Maka dari pembahasan ini

Perilaku konsumsi dalam islam menunjukkan bahwa variabel Variety diartikan sebagai setiap perilaku seorang konsumen untuk menggunakan dan Seeking mempengaruhi Brand Switching Handphone pada mahasiswa FEBI IAIN memanfaatkan barang dan jasa untuk PALU.

memenuhi kebutuhan hidupnya. Namun 2. Berdasarkan hasil pengujian data yang islam memberikan penekanan bahwa fungsi diperoleh dapat diketahui dari tabel perilaku konsumsi adalah untuk memenuhi Coefficients variabel produk kebutuhan manusia baik jasmani dan ruhani sehingga mampu memaksimalkan fungsi kemanusiaannya sebagai hamba dan khalifah Allah Swt untuk mendapatkan kebahagiaan dunia dan akhirat. ${ }^{36}$

Dalam mengkonsumsi barang dalam berpengaruh positif dan signifikan terhadap minat (Y). Dengan nilai signifikan $0.000<$ 0.05 Maka dari pembahasan ini menunjukkan bahwa variabel Fitur Produk mempengaruhi Brand Switching Handphone pada mahasiswa FEBI IAIN PALU.

islam juga perlu memperhatikan etika dan 3. Dari hasil pengujian serentak yang dilakukan norma manakala seseorang ingin melakukan pada kedua variabel independen yaitu konsumsi. Beberapa etika tersebut Variety Seeking (X1) danFitur Produk (X2) diantaranya adalah: kesederhanaan, keadilan, kebersihan, halal dan thoyib, keseimbangan dan lain-lain.

\section{Kesimpulan}

Berdasarkan hasil analisis data yang dilakukan dan pembahasan yang telah dikemukakan, maka diperoleh kesimpulan sebagai berikut :

1. Berdasarkan hasil pengujian menggunakan spss 21.0 dapat diketahui dari tabel Coefficients variabel produk (X1) berpengaruh positif dan signifikan terhadap Islam, h 44.

${ }^{36}$ Mannan, Teori dan Praktek Ekonomi terhadap variabel dependen yaitu Brand Switching Handphone (Y), maka hasilnya menunjukkan bahwa kedua variabel secara serentak memberikan pengaruh positif dan signifikan terhadap Brand Switching Handphone. Hal ini dapat dilihat dari hasil uji tabel ANOVA, besar nilai Sig. yaitu $0.000<0.5$ yang artinya kedua variabel independen tersebut berpengaruh positif secara bersama-sama dan signifikan terhadap Brand Switching Handphone.

\section{Daftar Pustaka}

Alana, Aditya Yesika. "Pengaruh Citra Merek, Desain, dan Fitur Produk 
terhadap Keputusan Pembelian Handphone Nokia (Studi Kasus pada Mahasiswa Universitas Diponegoro)" Jurnal Ekonomi, 2014.

Anita, Siti Hamidah dan Desi. "Analisis Persepsi Citra Merek, Desain, Fitur Dan Pengaruhnya Terhadap Keputusan Pembelian Produk Handphone Samsung Berbasis Android (Studi Kasus Stie Pelita Indonesia)." Jurnal Ekonomi Vol 21 No 4, 2013.

Anto, Hendrie. Pengantar Ekonomika Makro Islami, Terjemahan. Yogyakarta: Ekonosia Cet 1, 2003.

Asmara, Anjas. "Faktor-faktor yang Mempengaruhi Brandswitching Pengguna Handphone Merek Nokia ke Handphone Merek Blackberry (Studi Kasus di Bandar Lampung)." Tesis, Universitas Lampung: 2012.

B.A, Arianto. "Pengaruh Atribut Produk, Harga, Kebutuhan Mencari Variasi dan Ketidakpuasan Konsumen terhadap Keputusan Perpindahan Merek dari Samsung Galaxy Series di Kota Malang." Jurnal Aplikasi Manajemen, Vol.2 No.2: 2011.

brandswitching.html., http://risetpemasaran.blogspot.com/2 012/07/konsep-dan-pengertian.

Dewanti. "Analisis Karakteristik Produk Dan Kebutuhan Variasi Produk Dalam Mempengaruhi Perpindahan Merek Air Mineral Vit (Studi Kasus : Konsumen Vit Ukuran Galon Di Jakarta Barat)." Jurnal Ekonommi, Universita Bina Nusantara Jakarta: 2011.
Fredy, Rangkuti. The Power of Brand. Jakarta: Pt Gramedia Pustaka Utama, 2002.

genggam/html.,http://id.wikipedia.org/wiki/t elepon.

http://daftar-harga-hp-androidterbaru.blogspot.com/2015/09/Daftar -Merk-HP-DI-Indonesia-PalingLengkap.html.

http://ekonomi.kabo.biz/2012/01/perpindaha n-merek-brand-switching.html.

http://saynotogaptek.blogspot.com/2012/03/a pa-itu-fitur-dalam-istilahteknologi.html.

https://bonteng.wordpress.com/2009/11/16/a tribut-produk/html.

https://sbm.binus.ac.id/2016/06/22/penyebab -terjadinya-brand-switching $/ \mathrm{html}$.

Ir. Sofyan Siregar, M.M. Metode Penelitian Kuantitatif. Jakarta: Kencana, 2013.

Irawan. "Pengaruh Kualitas Fitur, Desain, Iklan, Kepuasan Konsumen Dan Kebutuhan Mencari Variasi Terhadap Keinginan Berpindah Merek Handpone (Survai Pada Pengguna Handphone Di Kota Purwokerto)"." Jurnal Performence vol 11 no 1, Universitas Jendral Sudirman Purwekerto: 2010.

Islam/,http://Hendrakholid.Net/Blog/2010/04 /06/Prilaku-Konsumen-Dan-TeoriKonsumsi-Dalam-.

J.C, Peter J.P \& Olson. "Consumer Behavior and Marketing Strategy." ed.9: Mc Graw Hill 2010. 
Julianti, Haryadi Sarjono dan Winda. SPSS vs Lisrel Sebuah Pengantar, Aplikasi Untuk Riset . Jakarta: Salemba Empat, 2011.

Kahn. Manajemen Pemasaran dan Jasa. Bandung: Alfabeta, 1999.

Kanuk, Sciffman L.G \& L.L. "Consumer Behavior." New Jersey, Person International ed 10: 2010.

Khairah, Nur Miftahatul. "Pengaruh Harga Terhadap Keputusan Masyarakat Untuk Melakukan Cicil Emas di Pegadaian Syariah Cabang Palu Plaza." SKRIPSI IAIN PALU, 2017.

Mannan. Teori dan Praktek Ekonomi Islam. Yogyakarta: Dana Bhakti Prima Yasa, 1997.

Mentansari, Alens Diana. "Perilaku Brand Switching (Perubahan Merek) Pada Telepon Seluler Yang Dipengaruhi Oleh Reference Group (Kelompok Acuan) (Studi Pada Mahasiswa Psikologi Universitas Brawijaya Malang)." Jurnal Ekonomi, Universitas Brawijaya Malang: 2013.

Nurdin, N. (2016). The Roles of Information Technology in Islamic Bank Knowledge Management: A study of Two Syariah Banks in Palu. Hunafa: Jurnal Studia Islamika, 13(2), 181217. doi: https://doi.org/10.24239/jsi.v13i2.44 4.181-217

Nurdin, N., Novia, N., Rahman, A., \& Suhada, R. (2019). Potensi Industri Produk Makanan Halal Di Kota Palu. Jurnal Ilmu Ekonomi dan Bisnis Islam, 1(1), 1-12.

Palu., Surat Keputusan Menteri Agama Republik Indonesia Nomor 100/In.13/Kp.07.6/02/2019 Tentang
Pengangkatan Dekan Institut Agama Islam Negeri.

produk.html,

http://www.pendidikanekonomi.com/ 2012/07/pengertian-dan-manfaatatribut.

Putra, Yanuar Surya. "Analisis Brand Switching Handphone Blacberry di Salatiga." Jurnal Ekonomi, Salatiga: 2013.

R, Djan I \& Ruvendi. "Prediksi Perpindahan Penggunaan Merek Handphone Dikalangan Mahasiswa. ." Jurnal Ilmiah Binaniaga, 2014.

Rahmawati, Anita. Perilaku Konsumen dalam Ekonomi Islam. Yogyakarta: Idea Press, 2011.

Rianto, Nur. Dasar-dasar Ekonomi Islam. Solo: Pt Era Adicitra Intermedia, 2011.

Santoso, Rahmat Agus. "Analisis Perilaku Brand Switching Dalam Pembelian Produk Handphone." Jurnal Manajemen Bisnis, Vol 1, No 2: 2011.

Situmorang, Sri Rosari. "Analisis Bauran Produk Terkait Kecenderungan Peralihan Merek Handphone Nokia (dalam Ruang Lingkup Persepsi Mahasiswa S1 IPB)." Skripsi, IPB Bogor: 2012.

Solihan, Asmuni. Fikih Ekonomi Umar bin AI-Kaththab. Jakarta: Khalifah, 2010.

Sugiyono. Metode Penelitian Kuantitatif Kualitatif dan $R$ \& $D$. Bandung: Alfabeta, 2012. 
Sunyoto, Danang. Analisis Regresi dan Uji Hipotesis. Yogyakarta: CAPS, 2011.

Umar, Husein. Metode Riset Perilaku konsumen Jasa. Jakarta: Ghalia, 2003.

Wibowo, Setyo Fery. "Pengaruh Atribut Produk Dan Variety Seeking
Terhadap Keputusan Perpindahan Merek Handphone Nokia Ke Smartphone Samsung (Survei pada outlet Okeshop ITC Roxy Mas, Jakarta Pusat)." Jurnal Riset Manajemen Sains Indonesia (JRMSI), Vol 1: 2014. 